\title{
Evaluation of Diagnostic Efficiency of Ultrasonography in Temporomandibular Joint Disorders: A Pilot Study
}

\author{
Temporomandibular Eklem Bozukluklarında Ultrasonografinin Diagnostik Etkinliğinin \\ Değerlendirilmesi: Bir Pilot Çalışma \\ Mehmet Oğuz BORAHAN ${ }^{1}$, Gaye KESER ${ }^{1}$, Gamze ULAY ${ }^{1}$, Filiz NAMDAR PEKİNER ${ }^{1}$
}

\begin{abstract}
Objective: Temporomandibular Joint diseases (TMD) and disorders refer to a complex of conditions, manifested by pain in jaw area and associated muscles and limitations in the ability to make the normal movements of speech, facial expression, eating, chewing, and swallowing. Ultrasonography (US) is a noninvasive, cost-effective, easy-to-use imaging method using sound waves, without ionizing radiation and as a diagnostic procedure it has been shown to be accurate for the diagnosis of TMD. The purpose of this pilot study is to evaluate the diagnostic efficacy of ultrasonography imaging in temporomandibular joint disorders.

Material and Method: The retrospective ultrasonography images of 20 patients (female, male) who had been referred to Marmara University, Faculty of Dentistry, Oral Diagnosis and Radiology Clinic with a complaint related to Temporomandibular joint (TMJ) were evaluated in terms of condylar surface irregularities, joint space reduction and joint effusion.
\end{abstract}

Results: A total of 20 patients ( $\% 70$ female, $\% 30$ male, mean age: 33,75$)$ and $40 \mathrm{TMJ}$ were evaluated and in \% 15 erosive degenerative changes, in \% 82,5 condylar surface flattening and in $\% 27,5$ increased joint capsule width was observed.

Conclusion: Ultrasonography is a non-invasive technique suitable for visualization of TMJ and evaluation of TMD in routine clinical practice.

Keywords: Temporomandibular Joint Disorders, Ultrasound, Radiology

\section{Öz}

Amaç: Temporomandibular eklem hastalıkları (TMD) ve rahatsızlıkları, çene bölgesinde ve ilgili kaslarda ağrı ile ortaya çıkan ve normal konuşma, yüz ifadesi, yeme, çiğneme ve yutma hareketlerini k1sıtlayabilen durumları ifade eder. Ultrasonografi (US), invazif olmayan, düşük maliyetli, kullanımı kolay ve iyonlaştırıcı radyasyon olmaksızın ses dalgalarının kullanıldığı, bununla birlikte; diagnostik prosedür olarak TMD teşhisi için doğruluğu kanıtlanmış bir görüntüleme yöntemidir. $\mathrm{Bu}$ pilot çalışmanın amacı, temporomandibular eklem hastalıklarında ultrasonografik görüntülemenin tanısal etkinliğinin değerlendirmektir.

Gereç ve Yöntem: Temporomandibular eklem (TME) ile ilgili şikayetleri bulunan, Marmara Üniversitesi Diş Hekimliği Fakültesi Oral Diagnoz ve Radyoloji Kliniğine başvuran 20 hastanın (kadın, erkek) retrospektif ultrasonografi görüntüleri kondiler yüzey düzensizlikleri, eklem boşluğunda daralma ve efüzyon açısından değerlendirilmiştir.

Bulgular: Toplam 20 hasta (\% 70 kadın, \% 30 erkek, yaş ortalamas1 :33,75) ve 40 TME değerlendirilmiş ve $\% 15$ eroziv dejeneratif değişiklik, \% 82,5 kondiler yüzeyde düzleşme ve \% 27 oranlarında artan eklem kapsülü genişliği gözlenmiştir.

Sonuç: Ultrasonografi, TME' nin görüntülenmesi ve rutin klinik uygulamada TMD'nin değerlendirilebilmesi için uygun ve invaziv olmayan bir tekniktir.

Anahtar Kelimeler: Temporomandibular Eklem Bozuklukları, Ultrason, Radyoloji

\section{Introduction}

The chewing system in individuals is the unit responsible for the speech, chewing and swallowing of the body. This system consists of joints, ligaments, bones, teeth and supporting tissues and muscles. Furthermore, the coordination of these structural components is provided by neurological control systems (1).

Temporomandibular joint (TMJ) is composed of mandibular condyle, temporal bone, articular disc, ligaments

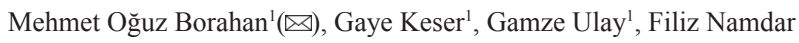
Pekiner $^{1}$

${ }^{l}$ Department of Oral Diagnosis and Radiology, Marmara University, Faculty of Dentistry, İstanbul, Turkey

oguzborahan@hotmail.com

Submitted / Gönderilme: 19.03 .2018

Accepted/Kabul: 05.04.2018 
and various muscles. It is a ginglimodiartrodial joint with a sliding axis, which is located below the temporal bone between the mandibular fossa and the mandibular condyle, in front of the external auditory canal (1-4). In this system, a biconcave-shaped dense fibrous connective tissue arises in the articulating disc $(1,4,5)$ in order to ensure the conformity of the articular surfaces between the mandibular mandible of the condyle head and the mandibular fossa at the temporal bone. Metabolic needs of the tissues are provided through synovial fluid containing mucopolysaccharide which makes the joint surfaces lubricious in the joint system. Since articular surfaces and discs do not contain blood vessels, the metabolic needs of the tissues are provided by synovial fluid that surrounds the joint surface and at the same time lubricates the joint surfaces $(3,4,6,7)$.

Temporomandibular joint dysfunctions (TMD) are manifested by limitations of normal jaw movements, speech, facial expressions, eating, drinking and swallowing functions and pain in the jaws which affect chewing muscles (8-12). According to the World Health Organization (WHO) report, temporomandibular dysfunction is one of the most common diseases in the mouth and jaw region (13). According to the Diagnostic Criteria for Temporomandibular Joint Disorders (CDC / TMD) scale, the most important symptoms of Temporomandibular dysfunction (TMD) are noise (click, creep) and reduction (14-16).

Among the TMJ dysfunctions, the deviations are the most frequently seen (17-19). Patients with TMJ disorders often complain of tenderness, pain, difficulty in opening the mouth, and tenderness in the TMJ region and these complaints are the reasons for referral to patients' clinics. In the diagnosis of TMD, history and clinical examination results should be correlated with radiological findings (4).

Different imaging modalities are used in examining the anatomical structures of TMJ complex. Prevention of exposing the patient to unnecessary radiation dose is important in selecting the imaging method $(4,11,20-22)$. Computerized tomography (CT), magnetic resonance imaging (MRI) and arthrography are the most commonly used methods of imaging TMJ, and MRI is accepted as the gold standard in the literature (23-26). However, despite its advantage in imaging, features such as an expensive imaging technique, the inability to use in cardiopulmonary patients and heart pacemakers limit the use of MRI (27).

Ultrasonography (US) is a noninvasive, low cost, easy to use imaging method which transmits high-frequency sound waves to the tissue through a probe (transducer). In this technique, sound waves reflected from textures of varying intensities are subsequently displayed on a screen $(11,28$ 31). In US, a much higher (2-10 MHz) frequency of sound waves are used $(11,28,32,33)$. Ultrasonography can be used to diagnose disc displacements, effusion, intra-articular defects in TMJ $(32,33)$. In ultrasonographic images of the TMJ, the hyperechoic areas are the white areas representing the margins of the bone and joint capsule, the hypoechoic areas are the black areas representing the bone tissue, empty space, and water, and the isoechoic or grey areas represent the connective tissue and muscular tissue $(34,35)$. When TMJ is displayed, information about joint space, joint disc position, joint fluid and ligament adhesions can be obtained using a linear probe with a frequency of 7.5-12 MHz (28).

Imaging of TMJ and articular disc was first performed by Nebeith and Speculand (36) in 1991 using a $3.5 \mathrm{MHz}$ probe. Stefanoff et al. (37) have shown successful results in asymptomatic patients using a $5 \mathrm{MHz}$ probe. Based on the TMD studies in literature between 1991 and 2006, Melis et al. (20) reported that US has a sensivity of $13-100 \%$ in disc displacement, $70.6-83.9 \%$ in effusion, and $70-94 \%$ in condylar erosion. These studies portrayed the diagnostic reliability of ultrasonography in the diagnosis of TMJ disorders. Therefore, the aim of this study is to evaluate the diagnostic efficacy of ultrasonography imaging in temporomandibular joint dysfunctions.

\section{Materials and Method}

The study evaluated 20 patients and 40 joints with a mean age of 33.7 years who are over 15 years of age, with complaints of TMD and records of USG images. 20 patients over 15 years old from the archive in Oral and Maxillofacial Radiology Department, who had complaints of TME, who did not use any medication for bone diseases and who don't have any developmental anomalies were included in the study. Confirmation for the study was acquired from the Department of Non-invasive Clinical Research Ethics Committee, Marmara University Faculty of Medicine (Protocol No: 092016501). The written informed consent was acquired from each subject to inform about the study's object and procedure. This study was carried out to the recommendations of the Helsinki declaration.

Examinations were performed by using an Aloka Prosound $\alpha 6$ equipped with a $8 \mathrm{MHz}$-wide bandwidth linear active matrix transducer ranging from 1 to $15 \mathrm{MHz}$. Transcutaneous B mode images of the right and left TMJs 
were obtained with the patient in the supine position. The patient was asked to open and close their mouth and, on palpation of the pre-auricular region, an arbitrary position of the head of the condyle and TMJ was obtained (Figure 1). Once this position was achieved, a linear transducer was placed in a transverse direction in close contact with the skin. The transducer was then tilted obliquely until an optimal visualization of the head of the condyle was visible on the screen. The TMJ was assessed for the following parameters: destructive changes including condylar erosions, synovial width alterations and effusions (Figure 2-4).

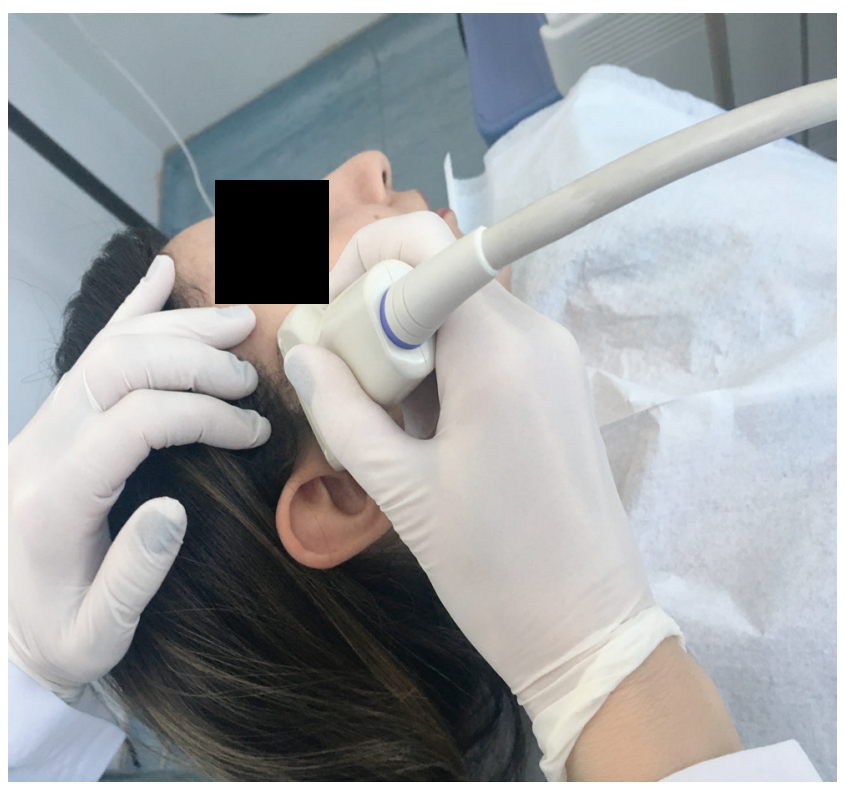

Figure 1. After obtaining position of the joint by palpation of the pre-auricular region, the transducer is placed in close contact with the skin with the mouth closed.

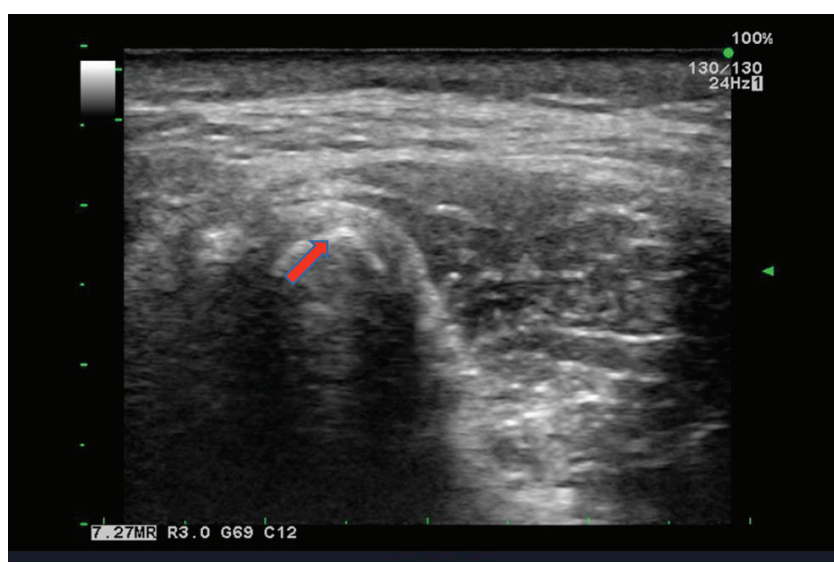

Figure 2. Joint surface irregularity. The surface of the condylar head appears hyperechoic and an irregularity can be appreciated on the margin.

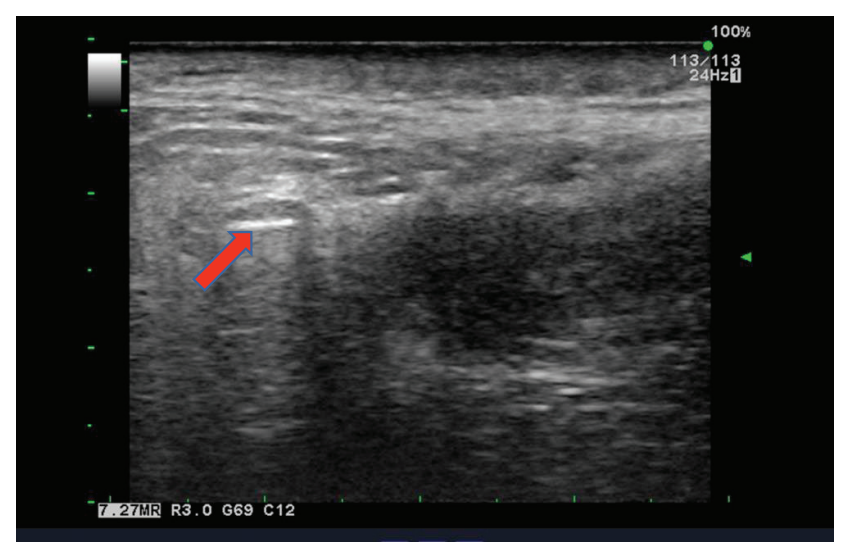

Figure 3. Flattening of the condylar surface

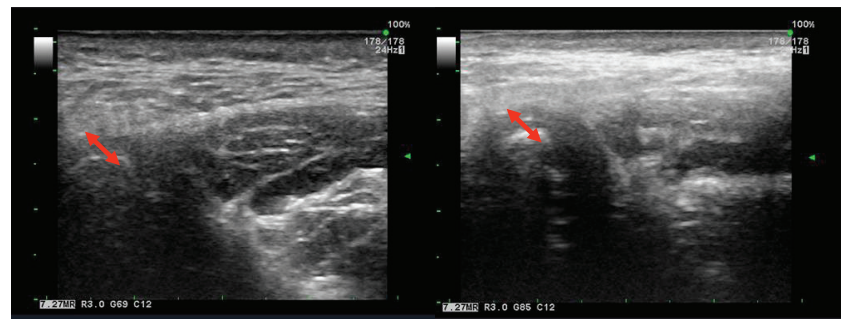

Figure 4. Increase in width of the approximating surfaces. This could be an indication of synovial width alterations.

\section{Results}

Ultrasonography was performed on all 40 TMJs. The examinations revealed that in $\% 15$ erosive - degenerative changes, in \% 82,5 condylar surface flattening and in \% 27,5 increased joint capsule width was observed. The results of the ultrasonography examinations of the TMJs are summarized in Table 1.

Table 1. Distribution of Temporomandibular Joint Disorders

\begin{tabular}{|c|c|c|c|}
\hline & Right & Left \\
\hline & & n (\%) & n (\%) \\
\hline \multirow{3}{*}{$\begin{array}{l}\text { condylar surface } \\
\text { irregularities } \\
\text { increase in joint } \\
\text { space width }\end{array}$} & $\begin{array}{l}\text { erosive-degenerative } \\
\text { changes }\end{array}$ & $4(20 \%)$ & $2(10 \%)$ \\
\hline & $\begin{array}{l}\text { condylar surface } \\
\text { flattening }\end{array}$ & $14(70 \%)$ & $19(95 \%)$ \\
\hline & & $4(20 \%)$ & $13(65 \%)$ \\
\hline
\end{tabular}

\section{Discussion}

Temporomandibular joint (TMJ); consists of the mandibular condyle which is separated from the mandibular fossa by an articular disc, ligaments, and muscles (3). TMJ disorders are 
recognized as one of the most common causes of orofacial pain and TMDs affect around $8-12 \%$ of the population $(27,34,38)$. In clinical practice, CT and MRI can help in the confirmatory diagnosis of hard-tissue and soft-tissue alterations in the TMJ, respectively, an effective screening modality is still lacking. Pathologies affecting the head and neck region, which includes the salivary glands, lymphatics, thyroid, nerves, and vascular structures, are accessible to ultrasound imaging and have been routinely imaged using ultrasonography $(27,39)$. However, reports on its use in the detection of TMDs in routine clinical practice are limited $(5,14,16,25,27)$. Magnetic resonance imaging (MRI) has been reported as the most precise method for visualizing the disc-condyle relationship (16). The accuracy of MRI is about $95 \%$ when sagittal and coronal scans are evaluated (14). With the advantages of being noninvasive and less expensive than other methods, US has been used as a new method for diagnosing TMJ disc displacement $(14,27,31)$.

The aim of this study was to evaluate the diagnostic efficacy of ultrasonography imaging in temporomandibular joint disorders. Emshoff et al.(40), conducted a study on 29 patients who were aged between 19 to 62 years. Accuracy was found to be $91 \%$ in closed mouth position and it was $93 \%$ in open mouth position. Another study was conducted by Emshoff et al. (41), on 208 patients who were aged 13 to 78 years. The sensitivity, specificity and diagnostic accuracy were $80-68 \%$ both in closed mouth-open mouth, $87-93 \%$ (closed mouth-open mouth) and 82-82\% (closed mouth - open mouth), which were lesser than those which were reported in a previous study. In the present study a total of 20 patients ( $\% 70$ female, $\% 30$ male, mean age: 33,75 ) and $40 \mathrm{TMJ}$ were evaluated in closed mouth position and in $\% 15$ erosive - degenerative changes, in $\% 82,5$ condylar surface flattening and in \% 27,5 increased joint capsule width was observed.

Byahatti et al. (42), conducted a study on 100 patients with a $12 \mathrm{MHz}$ transducer using dynamic ultrasonography. Sensitivity in closed mouth position was found to be $80 \%$, while in the open mouth position, it was found to be $76 \%$. Except for study of Byhatti et al. (42), in all the other studies, US diagnosis was compared to MRI diagnosis, as it has been so far described as the gold standard and the most reliable method in diagnosis of TMJ disorders (11, $14,20,40,41)$.

Bonafe et al. (43) found the estimated sensitivity to be $22.5 \%$ in closed mouth position, which was lower than that was seen in previous studies. The specificity in closed mouth position was $96.6 \%$. In 2001, Jank et al. (44) introduced the use of a high resolution transducer of $12 \mathrm{MHz}$ to visualize the TMJ structures more accurate. The authors reported the disc as a hypoechoic structure in the glenoid fossa surrounded by a hyperechoic rim. Their results, comparing ultrasonography with diagnoses based on MRI, achieved a sensitivity, specificity and accuracy at closed-mouth position of $78 \%$, and a sensitivity, specificity and accuracy of $61 \%, 88 \%$ and $77 \%$, respectively, at maximum-mouth opening position.

When MRI was taken as the gold standard, TMJ disorders in a majority of studies ranged from $41 \%-90 \%$ in disc displacement $(11,14,20,27,40,41)$. In case of TMJ effusion and condylar effusion, sensitivities ranged from $20-80 \%$ and $83 \%$ respectively $(11,27,40-42)$. In the available literature, it was found that ultrasonography was an acceptable diagnostic tool for detection of disc displacement, condylar erosion and articular effusion.

\section{Conclusion}

The present study has several limitations because of the small sample size and lack of High Resonance Ultasonography (HR-US) usage and MRI correlations with the ultrasonographic findings. Since our study sample is small we could not evalute the sensitivity and specivity in our study. Moreover, it can be concluded that, US with the added benefit of reduced cost, remains another effective, noninvasive technique, to define the disk, its position, and the presence of TMJ internal derangements. Future studies with larger sample sizes and MRI correlations need to be conducted.

\section{Acknowledgement}

This study was presented as an oral presentation by Gaye Keser in 22 $2^{\text {nd }}$ BaSS Congress, Thessaloniki, May 4-7, 2017.

\section{References}

1. Okeson JP. Management of Temporomandibular Disorders and Occlusion, 7th ed. St. Louis: MO Elsevier; 2013.

2. Kavuncu V. Temporomandibular EklemDisfonksiyon Sendromu. In: Göksoy T, ed. Romatizmal Hastalıkların Tanı ve Tedavisi. İstanbul: Yüce Basımevi; 2002; 791-802.

3. Odabaş B, Arslan SG. Temporomandibuler Eklem Anatomisi ve Rahatsızlıkları. Dicle Tip Derg. 2008; 35(1): 77-85. 
4. Yıldırm D, Alkış Ü. Temporomandibular Eklem Bozukluklarının Değerlendirilmesinde Kullanılan Görüntüleme Yöntemleri. SDÜ Sağlık Bilimleri Enstitüsü Dergisi. 2016; 7(2): 52-56.

5. Gallo LM. Modeling of Temporomandibular Joint Function Using MRI and Jaw-Tracking Technologies-Mechanics, Cells Tissues Organs. 2005; 180 (1): 54-68.

6. Yengin E. Temporomandibular Rahatsızlıklarda Teşhis ve tedavi. İstanbul: İstanbul Üniversitesi Diş Hekimliği Fakültesi Yayınları; 2000.

7. Miloğlu Ö.(2009). Temporomandibular Eklem Disfonksiyonu Olan Hastalardaki Kondiller Kemik Değişikliklerinin İnternal Düzensizlik (Disk Deplasmanı) ile Olan İlişkisinin İncelenmesi. Atatürk Üniversitesi Sağlık Bilimleri Enstitüsü, Doktora Tezi, Erzurum, (Danışman: Prof. Dr. Ahmet Berhan Yilmaz)

8. Etoz M, Ozdemir ST, Sigırlı D, Demirbas, AE, Ercan I, Etoz OA, et al. Evaluation of bony structures on panoramic radiographs with statistical shape analysis in patients with temporomandibular joint pain and limited mouth opening. E-J Dent 2013;3:495-500.

9. Tanaka E, Detamore MS, Mercuri LG. Degenerative disorders of the temporomandibular joint: etiology, diagnosis, and treatment. J Dent Res 2008;87:296-307.

10. De Leeuw R. Orofacial pain. Guidelines for assessment, diagnosis, and management. 4th ed. Hanover Park: Quintessence Publishing; 2008.

11. Kundu H, Basavaraj P, Kote S, Singla A, Singh S. Assessment of TMJ Disorders Using Ultrasonography as a Diagnostic Tool: A Review. JCDR 2013;7(12):3116-3120

12. Malik A Neelima. Textbook of Oral and Maxillofacial Surgery. 2nd ed; Jaypee Brothers: Delhi.2008;240.

13. Pihut M, Szuta M Ferendiuk E, Zenczak - Wieckiewicz D. Differential Diagnostics of Pain in the Course of Trigeminal Neuralgia and Temporomandibular Joint Dysfunction. Biomed Res Int 2014; 2014: 1-7.

14. Jank S, Zangeri A, Kloss F, Laimer K, Missmann M, et al. High Resolution ultrasound investigation of the temporomandibular joint in patients with chronic polyarthritis. Int J Oral Maxillofac Surg 2011;40:45-49.

15. Truelove EL, Sommers EF, Leresche L, Dworkin SF, von Korff M. Clinical diagnostic criteria for TMD. New classification permits multiple diagnoses. J Am Dent Assoc 1992;123:47-54.

16. Katzberg RW, Westesson PL, Tallents RH, Drake CM. Anatomic disorders of the temporomandibular joint disc in asymptomatic subjects. J Oral Maxillofac Surg 1996;54(2):147-155.

17. Nekora-Azak A, Evlioğlu G, Ordulu M, Işsevver H, Prevalence of symtoms associated with temporomandibular disorders in a Turkish population. J Oral Rehabil 2006; 33(2):81-84.

18. Dos Anjos Pontual ML, Freire JS, Barbosa JM, Fraza ̃ MA, dos Pontual A Anjos. Evaluation of bone changes in the temporo-mandibular joint using cone beam CT. Dentomaxillofac Radiol 2012;41:24-29.
19. Mengel R, Kruse B, Flores-de-Jacoby L. Digital volume tomography in the diagnosis of periodontal defects: an in vitro study on native pig and human mandibles. J Periodontol 2005; 76:665-673.

20. Melis M, Secci S, Ceneviz C. Use of ultrasonography for the diagnosis of temporomandibular joint disorders: a review. Am J Dent 2007;20(2):73-78.

21. Petrikowski CG. Diagnostic Imaging of the Temporomandibular Joint. White SC, Pharoah MJ, 5th ed. Oral Radiology, Principles and İnterpretation. St Louis Missouri: Mosby; 2004: 538-576.

22. Brooks SL, Brand JW, Gibbs SJ, Hollender L, Lurie AG, Omnell KA, Westesson PL, White SC. Imaging of The Temporomandibular Joint. A position paper of American Academy of Oral and Maxillofacial Radiology. Oral Surg Oral Med Oral Pathol Oral Radiol Endod 1997; 83 (5): 609618.

23. Junior Mello C, Saito Cassio O, Filho H. Sonographic evaluation of temporomandibular joint internal disorders. Radiol Bras 2011;44(6): 355-359.

24. Hatala MP, Westesson PL, Tallents RH, Katzberg RW. TMJ disc displacement in asymptomatic volunteers detected by MR imaging. J Dent Res 1991;70:278-283.

25. Katzberg RW. State of the art temporomandibular joint imaging. Ann R Aust Cell Dent Surg 1989;10:32-52.

26. Kirkos LT, Ortendahl DA, Mark AS, Arakawa M. Magnetic resonance imaging of the TMJ disc in asymptomatic volunteers. J Oral Maxillofac Surg 1987;45(10):852-854.

27. Elias F, Birman EG, Matsuda CK, Oliveira IR, Jorge WG. Ultrasonographic findings in normal temporomandibular joints. Braz Oral Res 2006;20(1):25-32.

28. Tvrdy P. Methods of imaging in the diagnosis of temporomandibular joint disorders. Biomed Pap Med Fac Univ Palacky Olomouc Czech Repub. 2007; 151 (1): 133136.

29. Som PM, Curtin HD. Head and neck imaging, 3th ed. Volume I. St. Louis: Mosby; 1996; 375-433.

30. Choi YS, Jung HD, Kim SY, Park HS, Jung YS. Remodelling pattern of the ramus on submentovertex cephalographs after intraoral vertical ramus osteotomy. British Journal of Oral and Maxillofacial surgery 2013; 51 (8): 259-262.

31. Hayashi T, Ito J, Koyama J, Yamada K. The accuracy of sonography for evaluation of internal derangement of the temporomandibular joint in asymptomatic elementary school children: comparison with MR and CT. J Neuroradiol 2001; 22 (4): 728-734.

32. Tatlı U, Keleş B, Esen E, Öztunç H. Unilateral Kondiler Hiperplazinin Konik Işınlı Bilgisayarlı Tomografi İle Değerlendirilmesi: İki Olgu Sunumu Ve Literatür Derlemesi. Atatürk Üniv Diş Hek Fak Derg 2010; 20 (3): 198-204.

33. Scarfe WC, Farman AG, Sukovic P. Clinical Applications of Cone-Beam Computed Tomography in Dental Practice. J Can Dent Assoc 2006; 72 (1): 75-80.

34. Thomas, A.E., Kurup, S., Kumar, S.P. et al. Diagnostic efficiency of high-resolution ultrasonography in patients with chronic temporomandibular disorders. Oral Radiol 2016; 32: 160 . 
35. Merritt CRB. Physics of ultrasound. 2nd ed. St. Louis: Mosby;1998. p. 3-55.

36. Nebeith YB, Speculand B. Ultrasonography as a diagnostic aid in temporomandibular joint dysfunction. A preliminary investigation. Int J Oral Maxillofac Surg 1991; 20(3):182186.

37. Stefanoff V, Hausamen JE, van den Berghe P. Ultrasound imaging of the TMJ disc in asymptomatic volunteers. Preliminary report. J Craniomaxillofac Surg. 1992; 20(8):337.

38. Motoyoshi M, Kamijo K, Numata K, Namura S. Ultrasonic imaging of the temporomandibular joint: a clinical trial for diagnosis of internal derangement. J Oral Sci 1998;40(2):8994.

39. Tasaki MM, Westesson PL. Temporomandibular joint: diagnostic accuracy with sagittal and coronal MR imaging. Radiology 1993;186(3):723-729.

40. 40.Emshoff R, Bertram S, Rudisch A, Gabner R. The diagnostic value of ultrasonography to determine the temporomandibular joint disk position. Oral Surg Oral Med Oral Pathol Oral Radiol Endod 1997;84(6):688-696.

41. Emshoff R, Jank S, Rudisch A, Walch C, Bodner G. Error patterns and observer variations in the high-resolution ultrasonography imaging evaluation of the disk position of the temporomandibular joint. Oral Surg Oral Med Oral Pathol Oral Radiol Endod 2002; 93(3):369-375.

42. Byahatti SM, Ramamurthy BR, Mubeen M, Agnihothri PG. Assessment of diagnostic accuracy of high-resolution ultrasonography in determination of temporomandibular joint internal derangement. Indian J Dent Res 2010 ;21(2):189194.

43. Dupuy-Bonafé I, Picot MC, Maldonado IL, Lachiche V, Granier I, Bonafé A. Internal derangement of the temporomandibular joint: is there still a place for ultrasound? Oral Surg Oral Med Oral Pathol Oral Radiol 2012 ;113(6):832-840. 